\title{
Renibacterium salmoninarum and Mycobacterium spp.: two bacterial pathogens present at low levels in wild brown trout (Salmo trutta fario) populations in Austrian rivers
}

\author{
M. R. Delghandi, S. Menanteau-Ledouble ${ }^{*}$ (D, K. Waldner and M. El-Matbouli
}

\begin{abstract}
Background: Renibacterium salmoninarum and Mycobacterium sp. are important bacterial pathogens of fish. $R$. salmoninarum is the causative agent of bacterial kidney disease, a Gram-positive bacterium mostly known for causing chronic infections in salmonid fish, while multiple species belonging to the Mycobacterium genus have been associated with mycobacteriosis in fish as well as in human. The objective of this study was to determine the prevalence of these two bacterial pathogens in populations of wild brown trout (Salmo trutta fario) in four rivers (Kamp, Wulka, Traun and Ybbs) in Austria.

Results: A total of 457 kidney samples were examined for both bacterial agents using nested and conventional PCR as well as bacterial cultivation on KDM-2, histological examination and immunohistochemistry. Molecular evidence showed an estimated prevalence level of $0.94 \%$ for $R$. salmoninarum in 2017 while the bacterium could not be detected in 2018 and histology showed signs consistent with a low-level chronic inflammation in the kidney of infected fish. Similarly, no fish were found positive for Mycobacterium in 2017 but in 2018, the prevalence was found to be $37.03 \%$ in the Kamp river (4.08\% across all rivers). The sequencing data confirmed that these fish carried Mycobacterium sp. although the precise species of Mycobacterium could not be ascertained.

Conclusions: This survey constitutes the first insight into the prevalence rate of $R$. salmoninarum and Mycobacterium sp. in wild brown trout (Salmo trutta fario) populations in Austria. Both of these pathogens were only detected in the summer months (June and July), which might suggest that the stress linked to increased water temperature could act as stressor factor and contribute to the outbreak of these diseases. The age of the fish might also play a role, especially in the case of Mycobacterium sp. as all the infected fish were in their first summer (June).
\end{abstract}

Keywords: Molecular epidemiology, Nested PCR, Proliferative kidney disease, Prevalence study, Wild populations, Salmo trutta fario

\footnotetext{
* Correspondence: menanteaus@staff.vetmeduni.ac.at

Clinical Division of Fish Medicine, University of Veterinary Medicine,

Veterinärplatz 1, 1210 Vienna, Austria
}

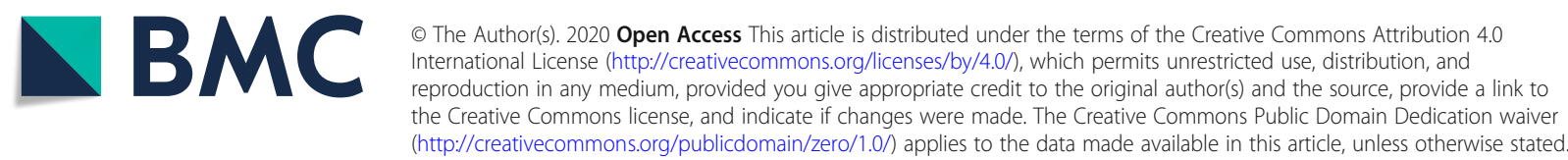




\section{Background}

Brown trout (Salmo trutta fario) is one of the native species of European salmonids and is an endemic inhabitant of Austrian rivers [1], while the rainbow trout (Oncorhynchus mykiss) has been broadly introduced from North America for farming purpose [2]. In the last several years, a decrease in brown trout populations has been reported in rivers in the Alpine region, including Austria, and repopulation efforts have proven insufficient to stop this downward trend [3].

Renibacterium salmoninarum is the causative agent of bacterial kidney disease (BKD) and a Gram-positive, non-acid-fast, non-motile, non-spore-forming, small $(0.1-1.0 \mu \mathrm{m}$ by $0.3-1.5 \mu \mathrm{m})$ diplobacillus [4, 5]. It is a fastidious, slow-growing organism with an optimal growth temperature ranging from 15 to $18^{\circ} \mathrm{C}$ [6]. BKD was first described in the 1930s in wild Atlantic salmon (Salmo salar) in the Dee river in Scotland [4] and R. salmoninarum was isolated for the first time from brown trout in the United States [7]. All salmonid fish species are susceptible to BKD although the range of susceptibility varies. For instance, rainbow trout and Atlantic salmon are comparatively resistant to BKD $[8,9]$ while two subfamilies of Salmonidae: Thymallinae, and Coregoninae are considered to be particularly sensitive [10]. BKD is a chronic, slow developing infection and has a significant impact on fish populations, both wild and farmed [11]. Mortality occurs mostly in 6 to 12 month-old juvenile salmon and pre-spawning adults [12]. Bacterial kidney disease has been reported in salmonids stocks all over the world except Ireland, Australia, New Zealand and the former Soviet Union [13].

$R$. salmoninarum is a facultative intracellular pathogen and several virulence factors have been identified [12]. P57 (57-kDa protein) is the best studied among these virulence factors and plays a significant role in cell agglutination and immune-suppression of the host [14-17]. Fish infected with $R$. salmoninarum can display external and internal clinical signs such as exophthalmia, blebs and blister on the epidermis with white or yellowish haemorrhagic fluid, petechiae and haemorrhages around the fins and lateral line, swelling of the kidney, heart, spleen, and liver alongside creamy-white and greyish granulomatous lesions on the surface of the viscera [18-20]. Notably, this organism has been associated with sub-clinical infections in salmonid fish and can establish asymptomatic infections in members of susceptible species [21].

$R$. salmoninarum is one of the most difficult bacterial pathogens of salmonid fish to control. No efficacious vaccines are currently available and it is known that wild fish can act as a reservoir and vector for the disease [12]. Antibiotic therapy against $R$. salmoninarum can be effective, but the bacterial reaction to treatment is slow and antibioticresistant strains have been reported [22-24]. A commercial vaccine based on Artherobacter sp. is available under the name of Renogen ${ }^{\bullet}$ but it is only commercialized in the USA, Canada and Chile. Moreover, it has been reported to only provide inconsistent levels of protection [20, 25].

In contrast with $\mathrm{BKD}$, mycobacteriosis can infect all fish species even if some species such as sea dragons and members of the seahorse family are particularly sensitive to this disease. Mycobacterium sp. are ubiquitous in the environment and have been isolated from both fresh and marine waters. These bacteria belong to the family Mycobacteriaceae of the order Actinomycetales and are acid-fast Gram-positive, non-motile and aerobic bacilli $[26,27]$ with an optimum growing temperature of 25$35^{\circ} \mathrm{C}$ [28]. The first aquatic Mycobacterium sp. was described in Carp in 1897 and was named Mycobacterium piscium [29], although it is now generally regarded that this isolate belonged to the species $M$. marinum [30]. Afterwards, Von Betegh reported the first M. marinum infection in captive marine fish in 1910 [31] and Norden and Linell identified the first $M$. marinum in human in Sweden in 1948 [32]. The first identification of M. chelonae was performed in 1903 from the sea turtle Chelona corticata and associated with mycobacteriosis in salmonid fish while $M$. fortuitum was first isolated from the neon tetra Paracheirodon innesi by Ross and Brancato in 1959 [33]. In the 1960ies, isolates of Mycobacterium sp. were isolated from salmon and named Mycobacterium salmoniphilum despite being classified, for a time, as a subspecies of $M$. chelonae, M. salmoniphilum is now considered its own species again [34].

Mycobacterium sp. have been allocated between four groups based on their growth rate and pigmentation pattern, according to the Runyon classification. These include photochromogenic Mycobacteriaceae (M. marinum and $M$. kansasii), scotochromogenic (M. gordonae and M. scrofulaceum), non-pigmented (M. avium, M. tuberculosis and $M$. ulcerans) and a fourth group that include faster growing mycobacteria that require approximately 5 days for growing on media (M. fortuitum, M. abscessus and M. chelonae) [33, 35]. Fish Mycobacteriosis or nontuberculous mycobacteria (NTM) is a chronic and granulomatous disease [36] and more than 150 species of Mycobacterium have been identified in relation with this disease. However, three species dominate the clinical landscape: M. marinum, M. fortuitum, and M. chelonae. These species are also zoonotic and can cause contagious skin infections, following exposure by immersion in contaminated water, in particular swimming pools, fishing, as well as interactions with live and dead fish [27, 29]. M. marinum has been related to granulomatous lesions on the skin (finger and hand) and deep tissues (tenosynovitis, osteomyelitis, and arthritis) [27]. Furthermore, $M$. chelonae and $M$. fortuitum have been associated with nontuberculous mycobacteria in immunocompromised patient that can affect skeletal system, skin, lymph nodes and respiratory system [37, 38]. 
Due to the chronic nature of the infection, infected fish may not show clinical signs and mortality may reach $50 \%$ without clinical signs [29]. When present, the clinical signs of piscine mycobacteriosis are non-specific and very similar to that of other diseases. These external signs include emaciation, skin ulceration, spinal deformity and behavioural change. Internal signs associated with Mycobacterium sp. infections are somewhat more specific and include organomegaly (spleen, kidney, and liver) with white and greyish nodules that can be observed in muscles [20, 27, 39]. Virulence of Mycobacterium sp. is associated with several pathways for instance several secretion systems such as secretion system-1 (ESX-1) to 5 (ESX-5). These secretion systems consist of MspA-like porins for the uptake and transport of nutrients as well as the virulent factor SecA2 [40-42].

There are currently only limited practical ways to treat Mycobacteriosis in fish. On one hand, many Mycobacterium sp. isolates have shown resistance to chemical disinfection [29]. On the other hand, while several antibiotics (rifampicin, streptomycin, erythromycin, ethambutol, isoniazid, tigecycline, and clarithromycin) are utilized to treat mycobacteriosis in aquaculture [26, 43, 44], the bacterium is not very responsive to treatment and require prolonged medication [29]. Moreover, antibiotic resistant isolates have been reported. In addition, while a DNA vaccine has been designed for mycobacteriosis in fish, it is not commercially available and there is currently no commercial vaccine against this disease [45].

Both bacterial agents (R. salmoninarum and Mycobacterium sp.) can be transmitted horizontally from infected fish or contaminated water supply as well as vertically from infected parents to eggs $[29,46,47]$. These pathogens can be identified by culture on selective mediums: $R$. salmoninarum is cultured on medium such as Kidney Disease Medium (KDM-1), KDM-2 as well as SKDM. While, Mycobacterium sp. can be isolated on Middlebrook 7H10, Löwenstein-Jensen and Middlebrook 7H9. Furthermore, various molecular and immunological procedures have been developed for the diagnosis $R$. salmoninarum and Mycobacterium sp. including PCR, ELISA, and FAT [20, 33].

Because both bacterial agents are known pathogens of wild fish and might play a role in the reported decrease of native brown trout populations in Austrian rivers, we decided to investigate the prevalence of $R$. salmoninarum and Mycobacterium sp. in wild brown trout in Austrian rivers. In particular, emphasis was made on $M$. marinum, as this is the best-established model for mycobacterial infections in fish.

\section{Results}

In total, 457 kidney samples were obtained from brown trout collected in 2017 (212 samples) and 2018 (245 samples). Genomic DNAs were extracted from kidney samples and PCRs were performed to detect the presence of these pathogens. Briefly, presence of R. salmoninarum was determined based on the protocol by Pascho et al. (1998) with slight alterations [48] and we identified two positive samples of $R$. salmoninarum (Fig. 1): One sample originated from the Kamp river and the other one from the Traun river. Both positive samples were collected in July 2017 from fish with a size of 17.5 and $20 \mathrm{~cm}$. The PCR results revealed no presence of $R$. salmoninarum in the Wulka or Ybbs rivers. Consequently, the prevalence of $R$. salmoninarum was estimated to be $2.32 \%$ in the Kamp, $0 \%$ in the Wulka, $1.69 \%$ in the Traun and 0\% in the Ybbs river in 2017 (Table 1). No R. salmoninarum positive samples were detected in 2018 and the results for $R$. salmoninarum revealed no significant difference between various rivers $(P=0.874)$.

Moreover, whenever the kidney samples were large enough, cultivation was attempted on KDM-2 agars and the rest of the organs were embedded in paraffin. Histological examination was performed as well as indirect immunohistochemistry using antibodies against $R$. salmoninarum. No bacteria could be isolated from the samples. However, glomerulus degeneration, alteration of renal corpuscles and tubules (Fig. 2a and b), membranous glomerulopathy and melanomacrophage aggregation were observed in the kidney samples positive for $R$. salmoninarum. This is consistent with a low-level chronic inflammation as caused by sub-clinical $R$. salmoninarum infection, although these histological alterations could be caused by other diseases targeting this organ. Moreover, weak signals were displayed by immunohistochemistry (Fig. 2c and d). Meanwhile, the negative samples exhibited no histopathological alterations.

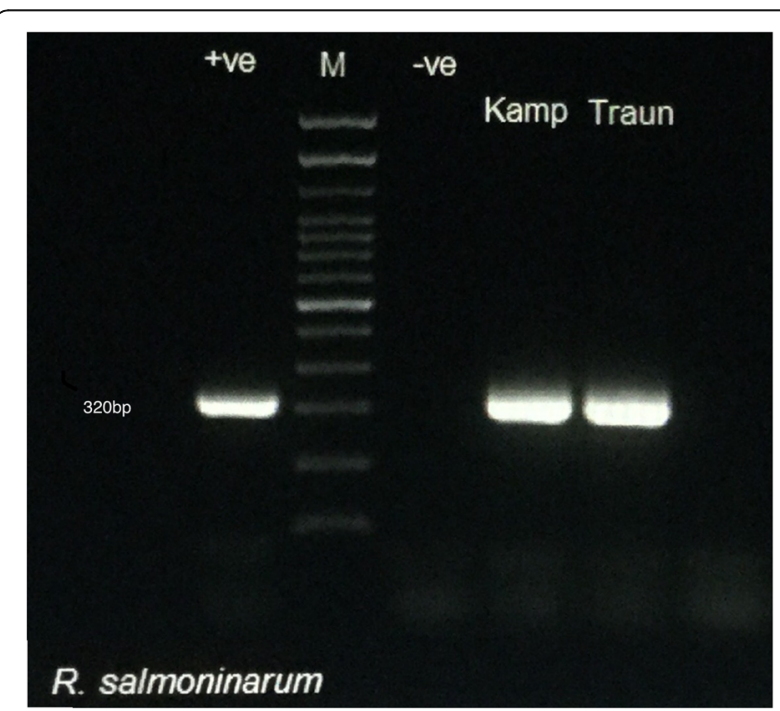

Fig. 1 Gel electrophoresis image showing the amplicons generated from the msa gene of $R$. salmoninarum positive samples in Kamp and Traun river according to the protocol by Pasch et al. [48] 
Table 1 Renibacterium salmoninarum and Mycobacterium sp. identified in wild brown trout (Salmo trutta fario) in kidney samples

\begin{tabular}{|c|c|c|c|c|c|c|}
\hline \multirow{2}{*}{$\begin{array}{l}\text { River } \\
\text { sites }\end{array}$} & \multicolumn{2}{|l|}{ Sampling } & \multirow{2}{*}{$\begin{array}{l}\text { Weight } \\
\text { (g) of } \\
\text { fish }\end{array}$} & \multirow{2}{*}{$\begin{array}{l}\text { Length } \\
(\mathrm{cm}) \text { of } \\
\text { fish }\end{array}$} & \multirow{2}{*}{$\begin{array}{l}\text { Number of } \\
\text { positive/ } \\
\text { prevalence } \\
\text { rate for } R \text {. } \\
\text { salmoninarum }\end{array}$} & \multirow{2}{*}{$\begin{array}{l}\text { Number of } \\
\text { positive/ } \\
\text { prevalence rate } \\
\text { for } \\
\text { Mycobacterium } \\
\text { sp. }\end{array}$} \\
\hline & Date & Number & & & & \\
\hline \multirow[t]{5}{*}{ Kamp } & July 2017 & 43 & $15-185$ & $10-28$ & $1 / 43(2.32 \%)$ & $0 / 43(0 \%)$ \\
\hline & Sep 2017 & 30 & $9-106$ & $9-22$ & 0/30 (0\%) & 0/30 (0\%) \\
\hline & May 2018 & 19 & 53-152 & $17-23$ & 0/19 (0\%) & 0/19 (0\%) \\
\hline & June 2018 & 27 & $0.1-0.5$ & $2.5-4.5$ & 0/27 (0\%) & 10/27 (37.03\%) \\
\hline & Nov 2018 & 62 & $3-141$ & $7-24$ & 0/62 (0\%) & $0 / 62(0 \%)$ \\
\hline \multirow[t]{4}{*}{ Wulka } & July 2017 & 16 & $4-392$ & $7-32$ & 0/16 (0\%) & 0/16 (0\%) \\
\hline & Sep 2017 & 25 & $4-201$ & $7-28.5$ & 0/25 (0\%) & 0/25 (0\%) \\
\hline & Oct 2018 & 3 & $5.5-310$ & $8-30$ & $0 / 3(0 \%)$ & $0 / 3(0 \%)$ \\
\hline & Nov 2018 & 20 & $6-27.5$ & $8-14.5$ & 0/20 (0\%) & 0/20 (0\%) \\
\hline \multirow[t]{4}{*}{ Traun } & July 2017 & 59 & $2-223$ & $7-28$ & 1/59 (1.69\%) & 0/59 (0\%) \\
\hline & Nov 2017 & 6 & $363-874$ & $34-41$ & 0/6 (0\%) & 0/6 (0\%) \\
\hline & May 2018 & 10 & $0.3-0.9$ & $3.5-4.5$ & 0/10 (0\%) & 0/10 (0\%) \\
\hline & Dec 2018 & 85 & $1.5-510$ & $5-35$ & 0/85 (0\%) & 0/85 (0\%) \\
\hline \multirow[t]{7}{*}{ Ybbs } & Sep 2017 & 23 & $4.5-166$ & $8-26$ & 0/23 (0\%) & $0 / 23(0 \%)$ \\
\hline & Dec 2017 & 10 & $25-145$ & $15-25.5$ & 0/10 (0\%) & 0/10 (0\%) \\
\hline & June 2018 & 10 & $0.2-0.5$ & $2.7-3.7$ & 0/10 (0\%) & 0/10 (0\%) \\
\hline & Nov 2018 & 9 & $8-69$ & $10-18$ & 0/9 (0\%) & 0/9 (0\%) \\
\hline & Total & 457 & & & 2/457 (0.43\%) & $10 / 457(2.18 \%)$ \\
\hline & 2017 & 212 & & & 2/212 (0.94\%) & 0/212 (0\%) \\
\hline & 2018 & 245 & & & 0/245 (0\%) & $10 / 245$ (4.08\%) \\
\hline
\end{tabular}

At the same time, the presence of Mycobacterium sp. was investigated using the primers and procedures designed by Talaat et al. [49], Telenti et al. [50] as well as a newly designed primer pair for $M$. marinum. All samples were screened with these three different molecular methods (Table 2). We did not detect any Mycobacterium sp. positive samples from the fish collected in 2017 using any of the PCR procedures. Mycobacteriaceae were similarly not detected in fish sampled from the Wulka, Traun or Ybbs river (Table 1). Furthermore, while Mycobacterium sp. was not detected in the Kamp river in 2017, in June 2018 ten positive samples were detected out of 27 samples collected, these results were consistent using all three of Talaat's, Telenti's and our primers (Fig. 3a, b and c). This increased the prevalence rate in the Kamp river to $37.03 \%$ for this month. Notably, none of the positive fish displayed clinical signs, although they had all died prior to sampling. Critically, all positive fish have been held in the same tank for several days before sampling that used a direct water input from the Kamp river without treatment the water. This time, a significant difference was found based on the place and time of sampling $(P<0.001)$. When comparing with the results of the screening for PKD, it was found that two samples were positive for both Mycobacterium and Tetracapsuloides bryosalmonae but the other 8 samples were not. Moreover, PKD was found within another three samples that were negative for Mycobacterium at the same sampling point. Consequently, there was no correlation between the prevalence of these infections $(P=0.309)$.

For both microorganisms, positive PCRs were repeated twice for positive samples in order to confirm the results. The resulting amplicons were excised from the agarose gel and purified using the MinElute Gel Extraction kit (Qiagen Inc) according to the producers' protocol. Purified products were sent for sequencing (LGC Genomics Company) using specific primer (P4 for $R$. salmoninarum as well as T531, Tb11 and Myco16 F1 for Mycobacterium sp.). All $R$. salmoninarum sequences and the sequences generated by T531 were submitted to GenBank under the accession number: PRJNA579289 (see also Additional file 1: Material S1).

For each reaction, $4 \mu \mathrm{l}$ of each primer at a concentration of 5 pmol were used and the resulting sequence were analysed for homology using Basic Local Alignment Sequence Tool (BLAST, National Center for 


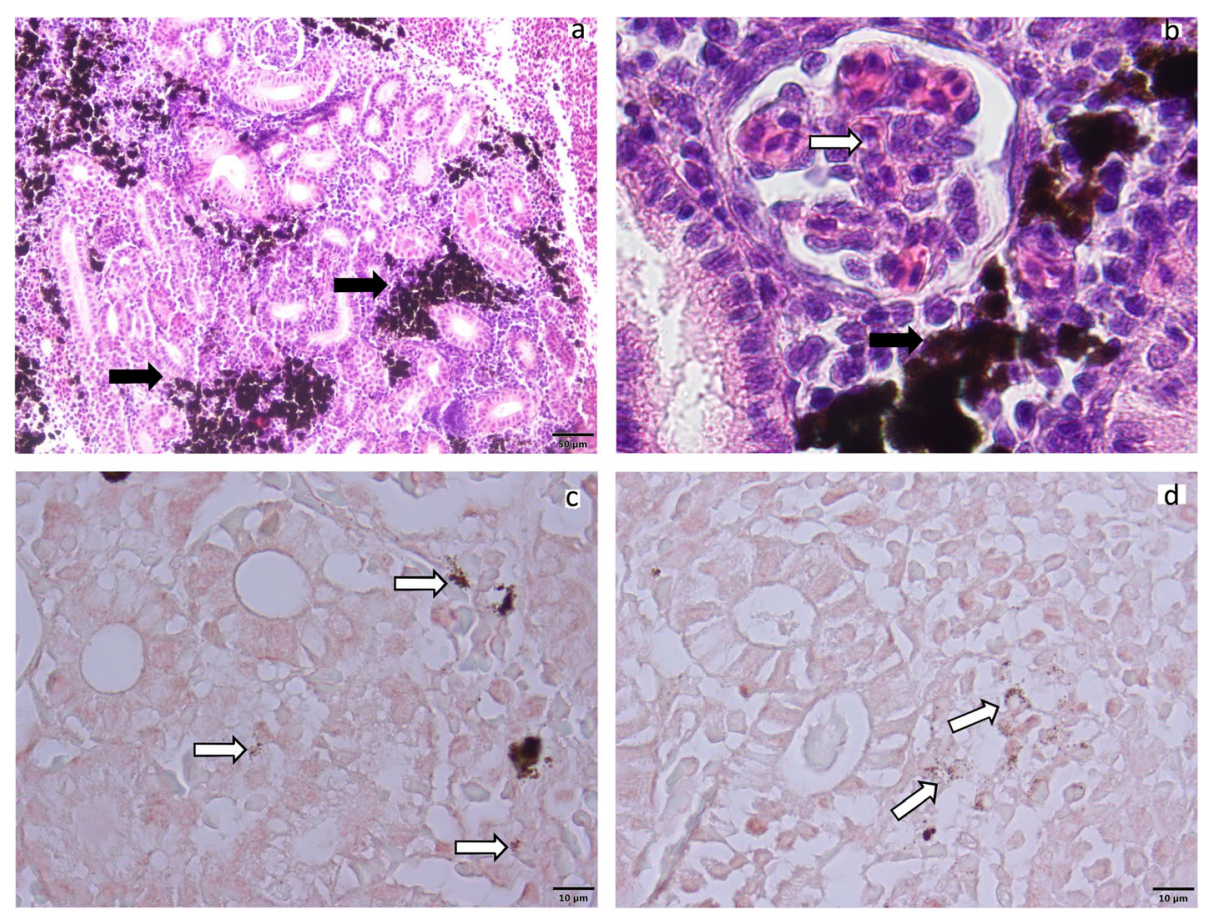

Fig. 2 Histological section of wild brown trout (Salmo trutta fario) kidney from the Kamp and Traum rivers. a: melanomacrophages aggregations were observed (black arrows). b: membranous glomerulopathy with ticking the hyaline, scale bar $=10 \mu \mathrm{m}$ (white arrows). c and d: Immunohistochemistry suggested low concentration of R. salmoninarum cells in golden brown color (white arrows)

Biotechnology Information), to confirm that the resulting sequences were homologous to that of the corresponding organisms. The sequencing results revealed that the homology level was $98.6-100 \%$ for the R. salmoninarum positive samples (Fig. 4). Sequences of the Mycobacterium sp. positive samples revealed a homology of $96.8-98.5 \%$ to multiple Mycobacterium species when using Talaat primers, $80 \%$ when using the Tb11 and Tb12 primers as well as $92-95 \%$ when using our custom primers (Fig. 5). Notably, neither of these primer pairs resulted in species-specific amplicons and all resulted in sequences with identical levels of homology for multiple Mycobacterium species.

\section{Discussion}

This study represents the first survey of the prevalence of $R$. salmoninarum and Mycobacterium sp. in wild brown trout populations in Austrian rivers. Screening of fish populations by PCR has been utilized in the past in other studies. For instance, when surveying rainbow and

Table 2 Primers used in this study

\begin{tabular}{|c|c|c|c|c|c|}
\hline Primer name & Target gene & Sequence $\left(5^{\prime}\right.$ to $\left.3^{\prime}\right)$ & Amplicon size (bp) & $\operatorname{Tm}\left({ }^{\circ} \mathrm{C}\right)$ & Reference \\
\hline P3 (outer F) & $m s a$ & AGCTTCGCAAGGTGAAGGG & 320 & 58.8 & [48] \\
\hline M21 (outer R) & msa & GCAACAGGTTTATTTGCCGGG & 320 & 59.8 & [48] \\
\hline P4 (inner F) & msa & ATTCTTCCACTTCAACAGTACAAGG & 320 & 59.7 & [48] \\
\hline M38 (inner R) & msa & CATTATCGTTACACCCGAAACC & 320 & 58.4 & [48] \\
\hline Мyсо 16 F1 & $16 \mathrm{~S}$ rRNA & AGCTCGTAGGTGGTTTGTCG & 611 & 59.4 & This study \\
\hline Myco 16 R1 & $16 \mathrm{~S}$ rRNA & CCACCTTCCTCCGAGTTGAC & 611 & 61.4 & This study \\
\hline$T_{39}$ (outer F) & $16 \mathrm{~S}$ rRNA & GCGAACGGGTGAGTAACACG & 300 & 63.9 & [49] \\
\hline $\mathrm{T}_{13}$ (outer R) & $16 \mathrm{~S}$ rRNA & TGCACACAGGCCACAAGGGA & 300 & 68.5 & [49] \\
\hline T43 (inner F) & $16 \mathrm{~S}$ rRNA & AATGGGCGCCAAGCCTGATG & 300 & 66.7 & [49] \\
\hline T531 (inner R) & $16 \mathrm{~S}$ rRNA & ACCGCTACACCAGGAAT & 300 & 53.7 & [49] \\
\hline Tb11 & Hsp65 & ACCAACGATGGTGTGTCCAT & 439 & 57.3 & [50] \\
\hline Tb12 & Hsp65 & CTTGTCGAACCGCATACCCT & 439 & 59.4 & {$[50]$} \\
\hline
\end{tabular}



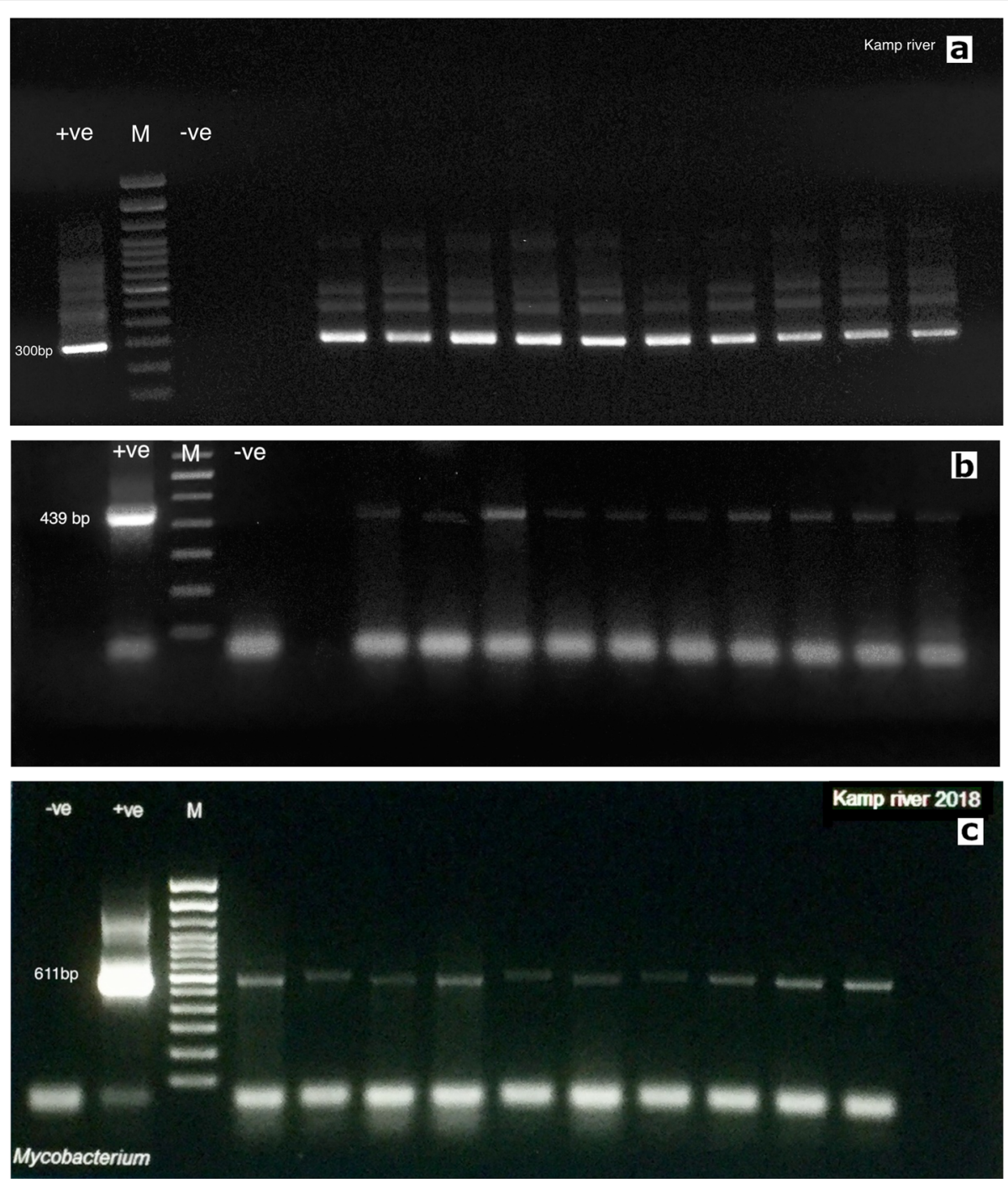

Fig. 3 a: Gel electrophoresis image showing the amplicons generated according to the nested-PCR procedure designed by Talaat et al. [49]. b: Gel electrophoresis image image showing the amplicons generated from the hsp65 gene of Mycobacterium sp. according to the protocol designed by Telenti et al. [50]. c: Gel electrophoresis image showing the amplicons generated from the 16S rRNA gene of Mycobacterium sp. using the custom primers designed in the present study

brown trout farming facilities in Slovenia in the winter 2010/2011, Pate et al. (2013) did not detect any $R$. salmoninarum positive fish [51]. On the other hand; a study by Chambers et al. (2008) [52] revealed a low prevalence $(0.8 \%)$ of the bacterium in wild brown trout in England and Wales which is comparable to our results from 2017. Moreover, distribution of R. salmoninarum was investigated in wild brown trout in Iceland through a combination of molecular and immunological methods, resulting in the discovery that all sampled fish
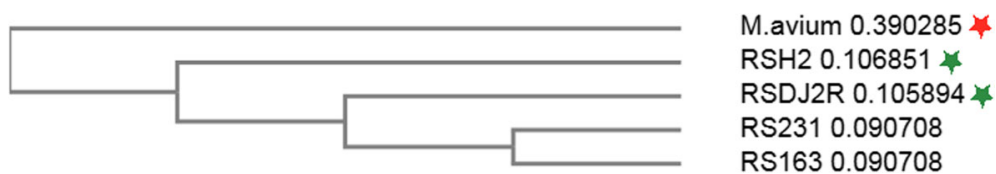

Fig. 4 Phylogenetic relationship of $R$. salmoninarum, isolated from wild brown trout based on msa gene. The reference strains $R$. salmoninarum DJ2R and R. salmoninarum H2 (both indicated with a green star) and the M. avium strain subsp. paratuberculosis MAPK_JJ1/13 (labelled with a red star) were added for comparison 


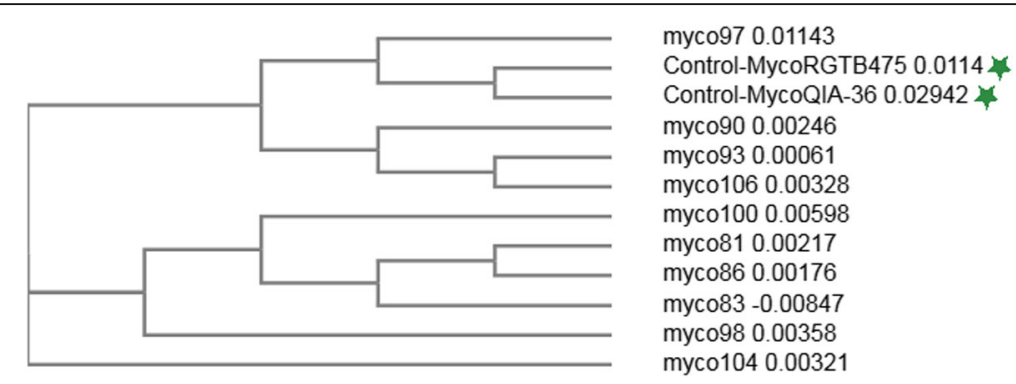

Fig. 5 Phylogenetic relationship of Mycobacteriaceae based on 16S rRNA sequenced amplified using the nested-PCR method described by Talaat et al. [49]. The reference strains M. avium RGTB475 and Mycobacterium sp. QIA-36 were also added for comparison and labelled with a green star

had been exposed to the bacterium [10]. In addition, $R$. salmoninarum has been detected in chum salmon (Oncorhynchus keta) in kidney and mucus samples by Suzuki et al. in 2017 in Japan. These authors indicated that $R$. salmoninarum could be identified from asymptomatic fish in sub-clinical stage of disease by using PCR [21]. Similarly, this organism has been identified in sub-clinical stage in the other different regions and species [53, 54].

Few studies have been conducted concerning the prevalence of Mycobacterium sp. in a randomly selected sample of clinically healthy wild fish population in their natural environment. The prevalence of mycobacteriosis in the freshwater fish is believed to be very low [55]. Abernethy et al. [56] reported low prevalence (8\%) of mycobacteriosis in the Mountain Whitefish Prosopium wiliamsoni and various mycobacterial species have also been identified in low prevalence (1.7\%) in freshwater fish in the Czech Republic [55]. In ornamental fish, screening of fish from 27 species from four different pet shop in Poland revealed that $M$. marinum could only be isolated from dwarf gouramis (Trichogaster lalius) tested all T. lalius were affected and these fish displayed clinical signs consistent with the infection. On the other hand, members of the other fish species sampled carried other species of Mycobacteriaceae [57]. Similarly, a high prevalence (46.8\%) of Mycobacterium sp. was reported in ornamental fish by Zanoni et al. (2008) in Italy [58]. Likewise, Slany et al. (2014) isolated $M$. marinum from ornamental fish in the Czech Republic with a comparable prevalence (41.7\%). The bacterium was also found in environmental samples (biofilms, sediment, water, and plant, 19.3\%) [59].

Mycobacteriosis in salmonid fish has most often been attributed to M. chelonae and M. salmoniphilum. However, previous study have shown that $M$. marinum could cause infections in rainbow and brown trout and Salogni et al. reported this pathogen from fish farms in Italy [60]. An outbreak of $M$. chelonae has been reported in Atlantic salmon (Salmo salar) in Scotland [61] and in British Columbia [62]. Asymptomatic piscine mycobacteriosis has been reported in some fresh water, hatchery-reared and juvenile Pacific salmonid populations infected by $M$. chelonae [62]. Furthermore, piscine mycobacteriosis attributed to M. salmoniphilum has been reported from Atlantic salmon farm in Norway by Zerihun et al. [63]. However, attempts at fulfilling Koch's postulate and replicate the mycobacteriosis artificially only resulted in the apparition of visible clinical signs after 131 days post-infection [63].

Remarkably, every sample positive for Mycobacterium sp. were sampled at the same time. Moreover, all these positive fish had been held together prior to sampling. It is therefore highly plausible that one infected fish had passed the infection horizontally to many of the surrounding fish; resulting in a much higher prevalence of the bacterium (37.03\% out of 27 samples) in June 2018. Other factors might have contributed to make the fish more sensitive to infection and it is possible that the environment might have been more suitable for the bacterium at that point. For example, Mycobacteriaceae have a higher optimum temperature than $R$. salmoninarum $[6,28]$. This resulted in a statistically significant effect of the date and river sampled on the prevalence of Mycobacterium $(P<0.001)$.

Notably, all the fish that were tested positive for Mycobacterium were of small size (approximately $2.9-4.5 \mathrm{~cm}$, Table 1). In contrast, the other fish that were caught from the Kamp river in 2017 and 2018 had a larger size. This finding could suggest that younger fish are more sensitive to infection, although it is difficult to reach any conclusions as all our positive samples originated from the same infectious event.

While no Mycobacterium were detected in the winter, this does not necessarily mean that these bacteria were absent from the fish: only a part of all brown trout in the river were sampled. Moreover, as stated below, it is well established that low levels of subclinical infection can escape detection. The fact that active infections can occur in the fish makes it very likely that the bacterium can survive in the organs during the colder months, even if the environmental conditions are below the ones preferred by the bacterium $[64,65]$ and might not allow for an active outbreak of the disease to take place in the winter. In this case, the infected fish might only start shedding the bacterium when the temperature rises. 
Due to the low levels of both bacterial agents during the healthy and asymptomatic carrier phase, detection of these diseases can be difficult. It is therefore possible that some infected fish were not detected and constituted false negatives. Indeed, Gudmundsdóttir et al. (2017) mentioned that the numbers of positive could be affected by the choice of identification procedures and organs tested. In their survey, the authors utilized five different detection methods (including pELISA, nPCR, two different qPCR and culture) and multiple organs including spleen, kidney, gills, oesophagus, and mid-gut [10]. In the current study, we were constrained by the fact that these samples had already been acquired as part of the Climate Trout project even if sampling other organs or performing ELISA on blood samples would have been beneficial. Presence of $R$. salmoninarum detected by molecular method could be confirmed by isolation of immunohistochemistry however, this is consistent with previous studies that have shown these methods to be less sensitive, especially in asymptomatic carriers.

In this survey, the source of BKD and mycobacteriosis in wild brown trout was unclear. It is plausible that both bacteria permanently exist at a low level within susceptible fish population, both wild and farmed and that the numbers of bacteria increase and outbreaks of the diseases appear when the populations become more susceptible. Several environmental parameters and risk factors are known to contribute to outbreaks of infectious diseases such as the interactions between physical, chemical, biological, and ecological factors [66] as well as poor water quality, fish density and stress [33]. Lapointe et al. (2014) indicated that summer temperatures and hypoxia can increase the prevalence of mycobacteriosis in striped bass [67]. Sudden changes in water temperature may act as a stress factor and increase fish susceptibility to pathogens especially in the spring and autumn. In the present study, the water temperature in both the Kamp and Traun rivers in July 2017 fluctuated between 16 and $20^{\circ} \mathrm{C}$ and between 16 and $22^{\circ} \mathrm{C}$ in June 2018. Our results did not indicate a statistically significant correlation between the presence of either bacterium and infections with T. bryosalmonae. Nonetheless, co-infections are a common occurrence in fish [68]. They are likely important in modulating the severity of infections and remain under-investigated. Overall, we suspect that several environmental factors such as water temperature, air temperature, water quality, the amount of oxygen dissolved in the water might contribute to outbreaks of these diseases.

\section{Conclusions}

In summary, according to our data, BKD and mycobacteriosis are not widespread diseases in wild brown trout and have low prevalence rates in Austrian rivers. However, the diseases are present as two fish infected with bacterial kidney disease were detected, one fish in the Kamp and another one in the Traun river in July 2017. Similarly, multiple fish infected with Mycobacterium sp. were identified in the Kamp river in June 2018. These wild populations can therefore constitute a reservoir for these diseases and transmission of pathogens between the wild and the farms is likely. However, we cannot rely on only one infectious event to clarify reservoir ability; this subject needs more research, especially in regard to the human health risks associated with fishing as sport in Austria mycobacteriosis. In the future, it would be of interest to repeat this investigation using other molecular diagnostics such as qPCR and identifying other genes, especially than 16S rRNA and hsp65 for Mycobacteriaceae. Moreover, multiple organs could be sampled instead of relying on the kidney alone and environmental presence of the bacteria should be considered, for example by investigating eDNA. It would also be of interest to investigate previous exposure of the fish to the bacteria using serological methods. Finally, it is worth noting that presence of the bacterium, as demonstrated by PCR does not automatically correlates with the establishment of disease. In the case of both of the bacteria studied, it is well established that the fish can remain as healthy carriers for prolonged periods of time [55], moreover it is possible that bacterial DNA could be present even in the absence of a viable bacterial pathogen or part of dead pathogen [69]. Consequently, the results of the screening should be confirmed with other methods to illustrate correlation between infection and disease.

\section{Methods}

\section{Sampling}

Wild brown trout were collected by electric fishing between 2017 and 2018 (457 fish samples in total, 212 in 2017 and 245 in 2018) in four Austrian rivers (Kamp, Wulka, Traun and Ybbs) (see map in Additional file 2: Figure S1) as part of the project ClimateTrout. The water temperature was measured during the samplings and ranged between 0 and $2{ }^{\circ} \mathrm{C}$ in the winter to $16-$ $22{ }^{\circ} \mathrm{C}$ in the summer. The ClimateTrout project aims at screening wild trout populations for the presence of $T$. bryosalmonae, the causative agent of PKD (proliferative kidney disease) and investigate the impact of climate change on the prevalence of this infection using PCR. Our samples were initially collected as part of this project and were further investigated to make the most use of the sacrificed fish. Briefly, the fish were humanely euthanatized by prolonged immersion in a solution of Tricaine Methanesulfonate (1 g/L; Sigma-Aldrich) and kidney tissues were sampled aseptically and brought on ice to the Vetmeduni Vienna. Whenever the organs were large enough, they were cut in two. Genomic DNA was extracted using a DNeasy blood and tissue kit (Qiagen 
Inc.) according to the manufacturers' protocol and stored at $-20^{\circ} \mathrm{C}$ until use. Then, for the organs that were large enough, the second part of the kidney was processed for bacterial isolation and histology as described below.

\section{Nested PCR assay for $m s a$ (major soluble antigen) gene $R$. salmoninarum}

Nested PCR based on the method of Pascho et al. (1998) was performed with slight alterations [48]. Two pairs of primers were utilized for the first (P3 and M21) and second round (P4 and M38) of PCR (Table 2). Briefly, the $25 \mu \mathrm{l}$ reaction mixture included $12.5 \mu \mathrm{l}$ of DreamTaq Green PCR Master Mix (ThermoFisher Scientific), $1 \mu$ of each primer $(10 \mathrm{pmol})$ and $8 \mu \mathrm{l}$ of DNA template was used for the first round while in the second round, $2 \mu \mathrm{l}$ of PCR product were used. For the first-round PCR denaturation of DNA $\left(95^{\circ} \mathrm{C}\right.$ for $\left.10 \mathrm{~min}\right)$ was followed by 30 cycles of amplification (denaturing at $94^{\circ} \mathrm{C}$ for $30 \mathrm{~s}$, annealing at $60^{\circ} \mathrm{C}$ for $30 \mathrm{~s}$ and extension at $72{ }^{\circ} \mathrm{C}$ for $1 \mathrm{~min}$ ). For the second round of PCR amplification, the procedure was similar to the first round, but performed for 20 cycles instead of 30 cycles. The PCR products ( $320 \mathrm{bp}$ in length) were run on a $1 \%$ agarose gel, stained with GelRed (Biotium) and compared to the expected size. Each PCR run included a no template control, a negative control (using genomic DNA from Aeromonas salmonicida) and a positive control (genomic DNA extracted from a pure culture of $R$. salmoninarum type strain RS20767).

\section{PCR assay for Mycobacterium sp.}

Mycobacterium sp. was detected using three PCR procedures (nested and conventional) and different primer pairs: Initially, we used Talaat et al. method (primers $\mathrm{T}_{39}$, $\mathrm{T}_{13}$, T43 and T531) for detection 16S rRNA gene based on nested PCR with slight modification [49]. Because sequencing did not result in species specific sequences, we also attempted to use the primers designed by Telenti et al. [50] to detect the $h s p 65$ (65-kDa heat shock protein) gene of Mycobacterium as well as designed one new primer pair (Myco 16 F1 and Myco 16 R1) that targeted the $16 \mathrm{~S}$ rRNA gene of $M$. marinum (Table 2).

All PCR reactions $(25 \mu \mathrm{l})$ contained $12.5 \mu \mathrm{l}$ of DreamTaq Green PCR Master Mix, $1 \mu \mathrm{l}$ of each primer (10 pmol) and $8 \mu$ of DNA template.

For the procedure designed by Talaat et al. [49], a first round of reaction was performed using the primers $T_{39}$ and $\mathrm{T}_{13}$ while in the second round, $2 \mu \mathrm{l}$ of PCR product were utilized as DNA template with this primer pair (T43 and T531). The amplification program of the both round consist of one cycle of $95^{\circ} \mathrm{C}$ for $5 \mathrm{~min}$, followed by 30 cycles of $94^{\circ} \mathrm{C}$ for $1 \mathrm{~min}, 50 \mathrm{C}^{\circ}$ for $1 \mathrm{~min}$ and extension at $72{ }^{\circ} \mathrm{C}$ for $1 \mathrm{~min}$. The nested PCR assay produces a $300 \mathrm{bp}$ amplification product on 1\% agarose gel.
For the PCR designed by Telenti et al, amplification consisted of one cycle of $95^{\circ} \mathrm{C}$ for $3 \mathrm{~min}$, followed by 45 cycles of $94^{\circ} \mathrm{C}$ for $1 \mathrm{~min}, 60^{\circ} \mathrm{C}$ for $1 \mathrm{~min}, 72^{\circ} \mathrm{C}$ for $1 \mathrm{~min}$ and extension for $10 \mathrm{~min}$ at $72^{\circ} \mathrm{C}$. The PCR assay produced a $439 \mathrm{bp}$ amplification product and was visualized by gel electrophoresis on a $1 \%$ agarose gel.

Finally, the amplification program for the new primer pair was carried out under the following conditions: $95^{\circ} \mathrm{C}$ for $5 \mathrm{~min}$ followed by 35 cycles of denaturing at $95^{\circ} \mathrm{C}$ for $1 \mathrm{~min}$, annealing at $54^{\circ} \mathrm{C}$ for $1 \mathrm{~min}$ and extension at $72^{\circ} \mathrm{C}$ for $1 \mathrm{~min}$. The resulting amplicon was 611 bp in size and was visualized by gel electrophoresis on a $1 \%$ agarose gel.

The positive control was prepared by extracting $M$. marinum DNA from a culture grown in Middlebrook $7 \mathrm{H} 9$ at $25^{\circ} \mathrm{C}$. Again, a no template control and a negative control (using genomic DNA from Aeromonas salmonicida) were included.

\section{Cultivation of R. salmoninarum on KDM-2 (kidney disease medium)}

Two positive and ten negative kidney tissue samples (from the Kamp and Traun rivers), as determined based on molecular diagnostic, were selected. These organs had been previously cut in two and the second half was further split. Part of the organ was lysed using a tissue lyser (Qiagen), inoculated on KDM-2 medium (1\% peptone, $0.05 \%$ yeast extract, $0.1 \%$ L-Cysteine, $1.5 \%$ agar and $20 \%$ foetal bovine serum) [70] and incubated at $15^{\circ} \mathrm{C}$ for 4 weeks. None of these plates produced any $R$. salmoninarum colonies.

Unfortunately, in contrast with the $R$. salmoninarum positive samples, all the samples that had been found positive for Mycobacterium originated from asymptomatic small fish. The kidneys were therefore found to be too small to cut and the entirety of the organ was used for DNA isolation. Therefore, these organs could not be processed for bacterial isolation or histological examination.

\section{Histopathology and immunohistochemistry}

The remaining kidney tissues were fixed in 10\% buffered formalin then embedded in paraffin and sectioned at a thickness of $5 \mu \mathrm{m}$. Half of the sections were then stained with haematoxylin and eosin (H\&E), and examined with light microscope.

The remaining microscope slides were prepared for immunohistochemistry using $100 \mu \mathrm{l}$ of reconstituted $R$. salmoninarum mouse monoclonal antibody AQUAMAB $\mathrm{P03}^{\circ}$ (Aquatic diagnostic Ltd) incubated for $2 \mathrm{~h}$ at room temperature in humid chamber. As a secondary antibody, horseradish peroxidase conjugated goat antimouse antibody was used. For staining, the Vetcastin ${ }^{\circ}$ $\mathrm{ABC}$ kit and the peroxidase solution ImmPACT ${ }^{\mathrm{TM}} \mathrm{AEC}$ (Vector Laboratories) were used and incubation was performed for about $10 \mathrm{~min}$. 
Moreover, two slides from the organs that had been found negative for $R$. salmoninarum were spiked with a resuspension of $R$. salmoninarum before exposure to antibodies. The resuspended bacteria were incubated at room temperature on the slides for $15 \mathrm{~min}$ before being washed off with phosphate buffered saline. These spiked sections were used as a positive control for the immunohistochemistry.

\section{Statistics}

The prevalence numbers calculated in the present manuscript were tested for homogeneity using a Levene's test before being compared using least significant difference test. All tests were performed using IBM SPSS Statistics 25 software (IBM).

\section{Supplementary information}

Supplementary information accompanies this paper at https://doi.org/10. 1186/s12917-020-2260-7.

Additional file 1: Material S1. Sequences obtained during the project. Additional file 2: Figure S1. Map of the sampling points. The three background colors represent the different watershed in Austria. Each sampling point is represented with a star. Original map produced by Pymouss44 and released on Wikimedia Common under the GNU Free Documentation License. Sampling points were added by the authors.

\section{Abbreviations}

BKD: Bacterial kidney disease; ESX-1: Secretion system-1; FAT: Fluorescent antibody technique; H\&E: Hematoxylin and eosin; hsp65: 65-kDa heat shock protein; KDM: Kidney disease medium; msa: Major soluble antigen; NTM: Nontuberculous mycobacteria; P57: 57-kDa protein; pELISA: Polyclonal enzyme-linked immunosorbent assay; PKD: Proliferative kidney disease; SKDM: Selective kidney disease medium

\section{Acknowledgments}

The authors want to thank Dr. Günther Unfer, MSc. Stefan Auer and MSc. Thomas Bechter for the organization of the fieldwork and electrofishing.

\section{Authors' contributions}

KW performed the initial sampling and the genomic DNA isolation. MRD performed the rest of the experimental work. He and SML wrote the manuscript while SML and MEL designed and supervised the study. The new primer pair was designed by MRD and SML. All authors have read and approved the manuscript.

\section{Funding}

Not applicable.

\section{Availability of data and materials}

The sequences generated during this study have been deposited in Entrez under Bioproject accession number PRJNA579289 and are included as supplemental files.

\section{Ethics approval and consent to participate}

The study was approved by the institutional ethics committee (Ethik- und Tierschutzkommission) at the University of Veterinary Medicine of Vienna and followed the guidelines of the national authority concerning the use of animals for field studies. Because the animals used were euthanatized immediately upon capture and not further experimented upon, no additional permissions were required for the sample collection as per Austrian law.

\section{Consent for publication}

Not applicable.

\section{Competing interests}

The authors declare that they have no competing interests..

Received: 27 May 2019 Accepted: 24 January 2020

Published online: 03 February 2020

\section{References}

1. Lewisch E, El-Matbouli M. A fish health survey of selected Austrian rivers: implications for stocking practices and a wide distribution of Tetracapsuloides bryosalmonae. Wien Tierarztl Monatsschr. 2018;105:81-91.

2. Williams JE, Isaak DJ, Imhof J, Hendrickson DA, McMillan JR. Cold-water fishes and climate change in North America. Reference Module in Earth Systems and Environmental Sciences. 2015. https://doi.org/10.1016/B978-012-409548-9.09505-1

3. Hari RE, Livingstone DM, Siber R, Burkhardt-Holm P, Guettinger $H$. Consequences of climatic change for water temperature and brown trout populations in Alpine rivers and streams. Glob Chang Biol. 2006;12(1):10-26.

4. Fryer JL, Sanders JE. Bacterial kidney disease of salmonid fish. Annu Rev Microbiol. 1981;35:273-98.

5. Austin B, Austin DA. Bacterial fish pathogens disease of farmed and wild fish. 6th ed. Switzerland: Springer International Publishing; 2016. p. 84-106.

6. Sanders JE, Fryer JL. Renibacterium salmoninarum gen. Nov., sp. nov., the causative agent of bacterial kidney disease in salmonid fishes. Int J Syst Bacteriol. 1980;30(2):496-502.

7. Belding $\mathrm{DL}$, Merrill B. A preliminary report upon a hatchery disease of the Salmonidae. Trans Am Fish Soc. 1935:65(1):76-84.

8. Starliper CE, Smith DR, Shatzer T. Virulence of Renibacterium salmoninarum to salmonids. J Aquat Anim Health. 1997;9(1):1-7.

9. Sakai M, Atsuta S, Kobayashi M. Susceptibility of five salmonid fishes to Renibacterium salmoninarum. Fish Pathol. 1991;26(3):159-60.

10. Guðmundsdóttir S, Applegate $\sqcup$, Árnason ÎÖ, Kristmundsson Á, Purcell MK, Elliott DG. Detecting Renibacterium salmoninarum in wild brown trout by use of multiple organ samples and diagnostic methods. Bull Eur Assoc Fish Pathol. 2017;37:31-40.

11. Bayliss SC, Verner-Jeffreys DW, Ryder D, Suarez R, Ramirez R, Romero J, et al. Genomic epidemiology of the commercially important pathogen Renibacterium salmoninarum within the Chilean salmon industry. Microb Genomics. 2018;4(9) http://www.microbiologyresearch.org/content/journal/ mgen/10.1099/mgen.0.000201.v.

12. Wiens GD. Fish Diseases and Disorders: Viral, Bacterial and Fungal Infections. 2nd ed. Wallingford: CAB International; 2011. p. 338-74.

13. Plumb JA. Health maintenance of cultured fishes: principal microbial diseases. Ames: CRC Press; 2018.

14. Fredriksen $\AA$, Endresen C, Wergeland $H$. Immunosuppressive effect of a low molecular weight surface protein from Renibacterium salmoninarum on lymphocytes from Atlantic salmon (Salmo salar L). Fish Shellfish Immunol. 1997;7(4):273-82.

15. Wiens GD, Pascho R, Winton JR. A single Ala139-to-Glu substitution in the Renibacterium salmoninarum virulence-associated protein p57 results in antigenic variation and is associated with enhanced $p 57$ binding to Chinook salmon leukocytes. Appl Environ Microbiol. 2002;68(8):3969-77 https://www.datascienceplus.com/standard-deviation-vs-standard-error/.

16. Rhodes MW, Kator H, Kaattari I, Gauthier D, Vogelbein W, Ottinger CA. Isolation and characterization of mycobacteria from striped bass Morone saxatilis from the Chesapeake Bay. Dis Aquat Org. 2004;61(1-2):41-51.

17. Wiens $\mathrm{GD}$, Dale $\mathrm{OB}$. Renibacterium salmoninarum p57 antigenic variation is restricted in geographic distribution and correlated with genomic markers. Dis Aquat Org. 2009:83(2):123-31

18. Zrnčić S, Radosavljević $V$. West Balkans regional aquatic animal disease diagnostic manual. Rome: Food and Agriculture Organization of the United Nations (FAO); 2017. p. 46-7. http://www.fao.org/3/a-i6848e.pdf

19. Richards CA, Murphy CA, Brenden TO, Loch TP, Faisal M. Detection accuracy of Renibacterium salmoninarum in Chinook salmon, Oncorhynchus tshawytscha (Walbaum) from non-lethally collected samples: effects of exposure route and disease severity. Prev Vet Med. 2017;145:110-20. https:// doi.org/10.1016/j.prevetmed.2017.06.001.

20. Elliott DG. In: Woo PTK, Cipriano RC, editors. Fish Viruses and Bacteria: Pathobiology and Protection. Wallingford, United Kingdom: CABI Publishing; 2017. p. 286-97.

21. Suzuki K, Misaka N, Mizuno S, Sasaki Y. Subclinical infection of Renibacterium salmoninarum in fry and juveniles chum salmon Oncorhynchus keta in Hokkaido. Japan Fish Pathol. 2017:52(2):89-95. 
22. Rhodes LD, Nguyen OT, Deinhard RK, White TM, Harrell LW, Roberts MC. Characterization of Renibacterium salmoninarum with reduced susceptibility to macrolide antibiotics by a standardized antibiotic susceptibility test. Dis Aquat Org. 2008:80(3):173-80.

23. Wiens GD, Rockey DD, Wu Z, Chang J, Levy R, Crane S, et al. Genome sequence of the fish pathogen Renibacterium salmoninarum suggests reductive evolution away from an environmental arthrobacter ancestor. J Bacteriol. 2008;190(21):6970-82.

24. Keen PL, Montforts MHMM. Resistance in the environment. Wiley Blackwell: New-Jersey, Canada; 2012.

25. Elliott DG, Wiens GD, Hammell KL, Rhodes LD. In: Gudding R, Lillehaug A, Evensen O, editors. Fish vaccination. Chichester: Wiley Blackwell; 2014. p. 255-72.

26. Chinabut S. In: PTK W, Bruno DW, editors. Fish disease and disorders: Viral, bacterial, and fungal infections. Wallingford: CAB international; 1999. p. 319-40.

27. Aubry A, Mougari F, Reibel F, Cambau E. Mycobacterium marinum. Microbiol Spectr. 2017;5(2):735-52.

28. Akbari S, Mosavari N, Tadayon K, Rahmati-Holasoo H. Isolation of Mycobacterium fortuitum from fish tanks in Alborz, Iran. Iran J Microbiol. 2014;6(4):234-9.

29. Gauthier DT, Rhodes MW. Mycobacteriosis in fishes: a review. Vet J. 2009;180(1):33-47.

30. Francis-Floyd R. Mycobacterial Infections of Fish. SRAC Publ. 2011;(4706):112. http://www.aces.edu/anr/fish/aquaculture/download/Fish Health and Treatment/SRAC 4706.pdf.

31. Clark HF, Shepard CC. Effect of environmental temperatures on infection with Mycobacterium marinum (Balnei) of mice and a number of poikilothermic species. J Bacteriol. 1963;86(5):1057-69 http://www.ncbi.nlm. nih.gov/pubmed/14080772.

32. Nordén \& Linell. A new type of pathogenic mycobacterium. Nature. 1951;168(4280):826.

33. Gauthier DT, Rhodes MW. In: Woo PTK, Cipriano RC, editors. Fish Viruses and Bacteria: Pathobiology and Protection. Wallingford, United Kingdom: CABI Publishing; 2017. p. 245-57.

34. Whipps CM, Butler WR, Pourahmad F, Watral VG, Kent ML. Molecular systematics support the revival of Mycobacterium salmoniphilum (ex Ross 1960) sp. nov., nom. Rev., a species closely related to Mycobacterium chelonae. Int J Syst Evol Microbiol. 2007;57(11):2525-31.

35. Runyon EH. Anonymous mycobacteria in pulmonary disease. Med Clin North Am. 1959:43(1):273-90

36. Novotny L, Dvorska L, Lorencova A, Beran V, Pavlik I. Fish: a potential source of bacterial pathogens for human beings. A review. Vet Med (Czech Republic). 2005;49(9):343-58 http://www.agriculturejournals.cz/web/vetmed. htm? volume $=49 \&$ firstPage $=343 \&$ type $=$ publishedArticle.

37. Lage R, Borba F, Santos C, Chimara E, Costa A. Mycobacterium chelonae cutaneous infection in a patient with mixed connective tissue disease. An Bras Dermatol. 2015;90(1):104-7.

38. Park S, Young G, Pyo M, Kim H, Kwon OJ, Soo K, et al. Clinical significance of Mycobacterium fortuitum isolated from respiratory specimens. Respir Med. 2008;102(3):437-42.

39. Hashish E, Merwad A, Elgaml S, Amer A, Kamal H, Elsadek A, et al. Mycobacterium marinum infection in fish and man: epidemiology, pathophysiology and management. A review Vet Q. 2018;38(1):35-46 https://www.tandfonline.com/doi/full/10.1080/01652176.2018.1447171.

40. De Jonge Ml, Pehau-Arnaudet G, Fretz MM, Romain F, Bottai D, Brodin P, et al. ESAT-6 from Mycobacterium tuberculosis dissociates from its putative chaperone CFP-10 under acidic conditions and exhibits membrane-lysing activity. J Bacteriol. 2007;189(16):6028-34.

41. Bensing BA, Seepersaud R, Yen YT, Sullam PM. Selective transport by SecA2: An expanding family of customized motor proteins. Biochim Biophys Acta (BBA)-Molecular Cell Res. 2014;1843(8):1674-86. https://doi.org/10.1016/j. bbamcr.2013.10.019.

42. Pradhan G, Shrivastva R, Mukhopadhyay S. Mycobacterial PknG targets the Rab711 signaling pathway to inhibit phagosome-lysosome fusion. J Immunol. 2018;201(5):1421-33 http://www.jimmunol.org/lookup/doi/10.404 9/jimmunol.1800530

43. Kawakami K, Kusuda R. Efficacy of rifampicin, streptomycin and erythromycin against experimental mycobacterium infection in cultured yellowtail. Nippon Suisan Gakkaishi Bull Japanese Soc Sci Fish. 1990;56(1):51-3 http://www.joi.jlc jst.go.jp/JST.Journalarchive/suisan1932/56.51?from=CrossRef.

44. Chang CT, Doerr KM, Whipps CM. Antibiotic treatment of zebrafish mycobacteriosis: tolerance and efficacy of treatments with tigecycline and clarithromycin. J Fish Dis. 2017;40(10):1473-85. https:/doi.org/10.1111/ffd.12619.
45. Muktar $Y$, Tesfaye S. Present status and future prospects of fish vaccination: a review. J Vet Sci Technol. 2016;07(02):299 https://www.omicsonline.org/ open-access/present-status-and-future-prospects-of-fish-vaccination-areview-2157-7579-1000299.php?aid=70000.

46. Bell GR, Higgs DA, Traxler GS. The effect of dietary ascorbate, zinc, and manganese on the development of experimentally induced bacterial kidney disease in sockeye salmon (Oncorhynchus nerka). Aquaculture. 1984;36(4): 293-311.

47. Pascho RJ, Elliott DG, Streufert JM. Brood stock segregation of spring Chinook salmon Oncorhynchus tshawytscha by use of the enzyme-linked immunosorbent assay (ELISA) and the fluorescent antibody technique (FAT) affects the prevalence and levels of Renibacterium salmoninarum. Dis Aquat Org. 1991;12(1):25-40

48. Pascho RJ, Chase D, McKibben CL. Comparison of the membrane-filtration fluorescent antibody test, the enzyme-linked immunosorbent assay, and the polymerase chain reaction to detect Renibacterium salmoninarum in salmonid ovarian fluid. J Vet Diagn Investig. 1998;10(1):60-6.

49. Talaat AM, Reimschuessel R, Trucksis M. Identification of mycobacteria infecting fish to the species level using polymerase chain reaction and restriction enzyme analysis. Vet Microbiol. 1997;58:229-37.

50. Telenti A, Marchesi F, Balz M, Bally F, Botrger EC, Bodmer T. Rapid identification of mycobacteria to the species level by polymerase chain reaction and restriction enzyme analysis. J Clin Microbiol. 1993;31(2):175-8.

51. Pate M, Zajc U, Ocepek M, Krt B, Jencic V. Zero prevalence of Renibacterium salmoninarum infection in rainbow and brown trout from Slovene fresh waters. Bull Eur Assoc Fish Pathol. 2013;33(5):136-43.

52. Chambers E, Gardiner R, Peeler EJ. An investigation into the prevalence of Renibacterium salmoninarum in farmed rainbow trout, Oncorhynchus mykiss (Walbaum), and wild fish populations in selected river catchments in England and Wales between 1998 and 2000. J Fish Dis. 2008;31(2):89-96.

53. Hirvelä-Koski V, Pohjanvirta T, Koski P, Sukura A. Atypical growth of Renibacterium salmoninarum in subclinical infections. J Fish Dis. 2006;29(1): 21-9.

54. Lovely JE, Cabo C, Griffiths SG, Lynch WH. Detection of Renibacterium salmoninarum infection in asymptomatic Atlantic salmon. J Aquat Anim Health. 1994:6(2):126-32.

55. Mrlik V, Slany M, Kubecka J, Seda J, Necas A, Babak V, et al. A low prevalence of mycobacteria in freshwater fish from water reservoirs, ponds and farms. J Fish Dis. 2012;35(7):497-504.

56. Abernethy CS, LUND JE. Mycobacteriosis in mountain whitefish (Prosopium williamsoni) from the Yakima River, Washington. J Wildl Dis. 1978;14(3):333-6.

57. Puk K, Banach T, Wawrzyniak A. Adaszek, Ziętek J, Winiarczyk S, et al. detection of Mycobacterium marinum, M. peregrinum, M. fortuitum and $M$. abscessus in aquarium fish. J Fish Dis. 2018;41(1):153-6.

58. Zanoni RG, Florio D, Fioravanti ML, Rossi M, Prearo M. Occurrence of Mycobacterium spp. in ornamental fish in Italy. J Fish Dis. 2008;31(6):433-41.

59. Slany M, Makovcova J, Jezek P, Bodnarova M, Pavlik I. Relative prevalence of Mycobacterium marinum in fish collected from aquaria and natural freshwaters in Central Europe. J Fish Dis. 2014:37(6):527-33.

60. Salogni C, Zanoni M, Covi M, Pacciarini ML, Alborali GL. Infezione da Mycobacterium marinum: descrizione di un focolaio di malattia in trota iridea (Oncorhynchus mykiss) e trota fario (Salmo trutta) d'allevamento. Ittiopatologia. 2007:4:227-37.

61. Bruno DW, Griffiths J, Mitchell CG, Wood BP, Fletcher ZJ, Drobniewski FA, et al. Pathology attributed to Mycobacterium chelonae infection among farmed and laboratory-infected Atlantic salmon Salmo salar. Dis Aquat Org. 1998:33(2):101-9.

62. Brocklebank J, Raverty S, Robinson J. Mycobacteriosis in Atlantic salmon farmed in British Columbia. Can Vet J. 2003:44(6):486.

63. Zerihun MA, Nilsen H, Hodneland S, Colquhoun DJ. Mycobacterium salmoniphilum infection in farmed Atlantic salmon, Salmo salar L. J Fish Dis. 2011;34(10):769-81.

64. Cardinal JL. Mycobacteriosis in striped bass, Morone saxatilis, from Virginia waters of Chesapeake Bay; 2001.

65. Baxa DV, Javidmehr A, Mapes SM, Teh SJ. Subclinical Mycobacterium infections in wild Delta smelt. Austin J Vet Sci Anim Husb. 2015;2(1):1004.

66. Hedrick RP, McDowell T, Groff J. Mycobacteriosis in cultured striped bass from California. J Wildl Dis. 1987;23(3):391-5.

67. Lapointe D, Vogelbein WK, Fabrizio MC, Gauthier DT, Brill RW. Temperature, hypoxia, and mycobacteriosis: effects on adult striped bass Morone saxatilis metabolic performance. Dis Aquat Org. 2014;108:113-27. 
68. Kotob MH, Menanteau-Ledouble S, Kumar G, Abdelzaher M, El-Matbouli M. The impact of co-infections on fish: a review. Vet Res BioMed Central. 2016; 47(1):1-12.

69. Josephson KL, Gerba CP, Pepper IL. Polymerase chain reaction detection of nonviable bacterial pathogens. Appl Environ Microbiol. 1993;59(10):3513-5.

70. Evelyn TPT. An improved growth medium for the kidney disease bacterium and some notes on using the medium. Bull Off Int Epizoot. 1977;87:511-3.

\section{Publisher's Note}

Springer Nature remains neutral with regard to jurisdictional claims in published maps and institutional affiliations.

Ready to submit your research? Choose BMC and benefit from:

- fast, convenient online submission

- thorough peer review by experienced researchers in your field

- rapid publication on acceptance

- support for research data, including large and complex data types

- gold Open Access which fosters wider collaboration and increased citations

- maximum visibility for your research: over $100 \mathrm{M}$ website views per year

At $\mathrm{BMC}$, research is always in progress.

Learn more biomedcentral.com/submissions 